\title{
Frozen conflict in the midst of a global pandemic: potential impact on mental health in Armenian border communities
}

\author{
Christopher Markosian $^{1} \cdot$ Vahe Khachadourian $^{2} \cdot$ Cheryl A. Kennedy $^{1}$
}

Received: 12 August 2020 / Accepted: 25 November 2020 / Published online: 3 January 2021

○) Springer-Verlag GmbH Germany, part of Springer Nature 2021

\begin{abstract}
Armenia has been in a conflict with its neighbor, Azerbaijan, since 1988. Civilians in Tavush Province are regularly affected by ceasefire violations along the armed border with recent escalations further threatening the population's safety. In the midst of the COVID-19 pandemic, concerns regarding the mental health of border village residents in Armenia are prevalent. We present context-related factors of psychiatric illness, the prevalence of mental health disorders, and the state of mental health services in Armenia. We recommend directing greater attention towards the mental health status of civilians residing in conflict zones during the ongoing COVID-19 pandemic.
\end{abstract}

Keywords Armenia $\cdot$ Coronavirus $\cdot$ Psychiatric health $\cdot$ Post-traumatic stress disorder

\section{Abbreviations \\ LMIC Low-to-middle-income country \\ PTSD Post-traumatic stress disorder}

SARS-CoV-2 Severe acute respiratory syndrome coronavirus 2

\section{Introduction}

Armenia, a landlocked nation of three million people in the South Caucasus [1], gained its independence from the Soviet Union in 1991. It has been in conflict with its neighbor, Azerbaijan, for over 30 years. An ethnic and territorial conflict over the disputed Nagorno-Karabakh region initiated a war between the two countries in 1988 that continued until a ceasefire agreement was reached in 1994 [2]. Nevertheless, regular violations of the ceasefire by armed military units have hampered the improvement of the tense situation [2, $3]$. The worst conflict since 1994, the 4-Day War, occurred in 2016 [3].

Christopher Markosian

christopher.markosian@rutgers.edu

1 Department of Psychiatry, Rutgers New Jersey Medical School, 183 South Orange Avenue, Newark, NJ 07103, USA

2 Gerald and Patricia Turpanjian School of Public Health, American University of Armenia, Yerevan, Republic of Armenia
Armenian villages located along the border with Azerbaijan, particularly in the northeastern Tavush Province, are regularly affected by the ceasefire violations. Shelling of buildings in these villages, which can be located less than one kilometer from the armed border, has resulted in civilian injuries. Despite a call for a global ceasefire by the Secretary-General of the United Nations [4], the conflict has severely escalated as of July 12, 2020, resulting in heavy shelling of multiple villages of Tavush Province to an extent unseen since the Nagorno-Karabakh War [5]. Recent reports revealed increased drone surveillance and missile threats against strategic locations, which would lead to profound civilian casualties [6]. Given these events and major impacts of the COVID-19 pandemic, at-risk communities in Armenia are likely experiencing a mental health crisis that deserves attention from both policymakers and researchers.

\section{Determinants of mental illness}

\section{Socioeconomic status}

Tavush Province is a rural region of Armenia. Generally, rural communities are associated with greater rates of suicide in comparison to their urban counterparts [7]. The economy of rural regions in Armenia largely depends on agriculture, including farming and cattle-breeding. Though rural communities tend to face higher rates of unemployment, the rate in Tavush Province $(28.4 \%)$ is the greatest in the country 
[8]. The high unemployment rates could be also attributable to the harsh economic conditions of Armenia in the early 1990s following the dissolution of the Soviet Union and the Nagorno-Karabakh War. Unemployment negatively affects mental health, especially in countries with weak economic development [9]. Due to the high unemployment rate, it is not uncommon for men to find employment in Russia and send remittances to their families in Armenia. The absence of men in a family-oriented society may also have emotional effects on their spouses and children by eliciting a sense of isolation [10]. These mental health-linked factors are commonplace in rural Armenia.

\section{Geopolitics}

Even though the conflict is considered frozen, concerns related to civilian mental health are active and widespread along the national border. About 44,000 civilians in Tavush Province live less than $5 \mathrm{~km}$ from the de jure border with Azerbaijan (Table 1). Residency in conflict or post-conflict zones is known to be associated with an increased risk for mental disorders [e.g., anxiety, depression, and post-traumatic stress disorder (PTSD)] [11-13]. However, the situation in the South Caucasus is distinct because of the limbolike status of the conflict, close proximity of civilians to the military units, and multi-generational impact. The risk of mental disorders may be accentuated due to unique circumstances along the Armenian-Azerbaijani border, such as (1) previous traumatic experiences associated with the conflict,
(2) fear of harm for oneself, family, and friends, (3) potential conflict eruption at any moment due to the fragile state of the ceasefire, and/or (4) severely limited work opportunities due to minimal safety in the region. Thus, determinants and risks of mental disorders in rural life are further compounded by border village-specific factors, making the Tavush Province population more susceptible to mental health issues.

\section{COVID-19}

The ongoing COVID-19 pandemic has further aggravated mental health concerns of these residents in Armenia. As of August 2, 39,050 cases and 754 deaths related to the severe acute respiratory syndrome coronavirus 2 (SARSCoV-2) have been recorded in the country [14]. With an infection rate of over $1 \%$, Armenia is among the worst-hit countries, ranking tenth in the world according to cases per million people at this time [15]. Many challenges due to the pandemic (resource shortages, financial losses, and public health directives such as quarantine) can be linked to poorer mental health [16, 17]. The risk of severe complications of coronavirus infection is likely higher in rural regions, especially among border communities, due to the limited access to specialized healthcare and widespread poverty (Tavush Province has a $28.9 \%$ rate of poverty, ranking fourth in the country) [18]. Furthermore, stress-related conditions promote immunosuppression and thus civilians of border communities could be more vulnerable to infection with SARSCoV-2 [19].

Table 1 Towns and villages of Tavush Province, Republic of Armenia in zones based on distance from the Republic of Azerbaijan and population

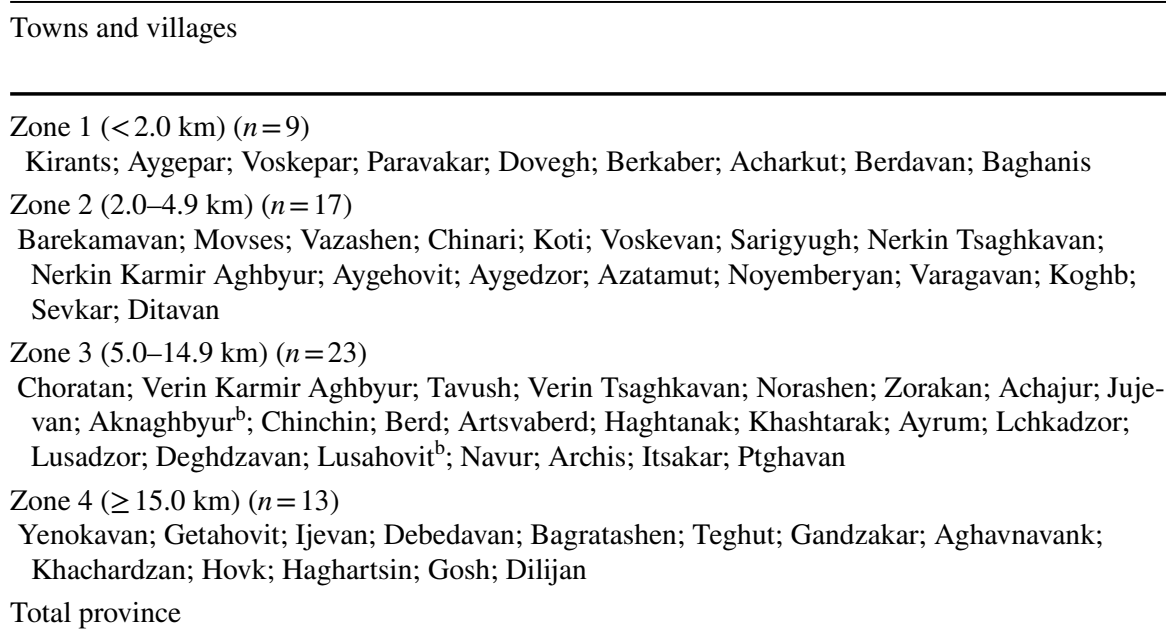

Distances were calculated using Google Maps in the United States, which utilizes United States-recognized borders and does not document the precise armed line of contact

${ }^{a}$ Source: Tavush Provincial Administration. About the Community. Ministry of Territorial Administration and Infrastructure. http://tavush.mtad. am/about-communities/. Accessed 22 July 2020

${ }^{\mathrm{b}}$ Population documented as of 2016 


\section{Culture and religion}

Despite the factors related to rural life, conflict zones, and health access inequalities that promote the risk of psychiatric illness, cultural characteristics of Armenia may counter it to some degree. A vast majority (92.7\%) of the population belongs to the Armenian Apostolic Church [20]. Religious involvement tends to be a positive coping mechanism against stress and is typically associated with less anxiety, depression, suicide, and substance abuse [21]. Furthermore, the family-oriented way of life is prevalent in Armenia and centers on trust, empathy, and promotion of autonomy and confidence [22]. Assistance among families of rural communities, stemming from altruistic motives, is also standard [23]. Intimate personal relationships are aspects of Armenian society, especially in rural villages, that may have a positive impact on mental health.

\section{Prevalence of mental health issues}

Mental disorders are estimated to impact about a quarter of the global population [24]. The combination of fragile security along the Armenian-Azerbaijani border and the severe consequences of the pandemic in Armenia call to attention the burden of mental disorders in the border villages of Tavush Province. However, social stigma is associated with mental health issues in the country [25], especially in these villages where emotions are considered to be "unnecessary baggage" in the struggle for survival [26]. Roberts et al., found high psychological distress in $21.7 \%$ of respondents in 2001 [27] and 5.5\% in 2010 [28]. Demirchyan et al. [29] revealed that more than a third of surveyed participants in the country were experiencing depression. Among Yerevan (capital city) residents of at least 65 years of age, Srapyan et al. [30] found that $76.0 \%$ in retirement homes and $81.2 \%$ in households had moderate to severe depressive symptoms. Furthermore, rural populations of Armenia are susceptible to experiencing mental illness years after traumatic events. Following the Spitak earthquake of 1988, a high proportion of affected residents continued to experience depression $(26.4 \%)$ and PTSD (15.5\%) in 2012 [31]. Data in border villages specifically is not available, but Berd Women's Resource Center reports that $86 \%$ of women experience mental health issues [32]. Abundance of risk factors for mental health illness and insufficient data from the population of Tavush Province located near the Armenian-Azerbaijani border call for further investigation to assess mental health issues in the region.

\section{State of mental health services}

Mental health services in Armenia are substandard similar to other post-Soviet states [33]. Treatment regimens are not regularly updated and research remains underdeveloped [34]. Only $3 \%$ of healthcare expenditure is directed towards mental health services, of which $88 \%$ goes to hospital care [35]. This makes psychiatric care largely inpatient, as hospitals contain excess beds and staff, leading to unnecessary admissions [34]. There is a need to expand outpatient psychiatric care at the community level, but there is a lack of mental healthcare providers, counselors, and social workers $[35,36]$. Only five outpatient mental health clinics, two of which are only for children and adolescents, are present in the country despite internal and external efforts to modernize mental healthcare $[36,37]$. Furthermore, most of the country's limited mental healthcare services are in Yerevan, while the remainder in the provinces stay outdated. Data is limited, but it is estimated that less than $1 \%$ of the Armenian population seeks psychiatric care [38].

Thus, mental health services in the rural regions of Armenia are less accessible [34]. Furthermore, rural Armenia is characterized by a shortage of specialists in comparison to Yerevan, acting as a barrier to obtaining specialized care [35]. Regardless, rural residents are likely to avoid seeking mental healthcare locally due to the lack of confidentiality in the patient-physician relationship [25]. Mental health services (including medications) for patients are free of cost and patients with chronic mental health issues can receive disability benefit payments [35]. However, these services are in need of rapid improvement given the stagnated progress and potential need among citizens.

\section{Conclusions}

The impact of the pandemic on the mental health of civilians residing in conflict zones is an important topic to address. Armenia is currently facing a high SARS-CoV-2 infection rate, regular shelling of border villages, and risk of another war. These factors undoubtedly impact the mental health of civilians, especially in the communities adjacent to the skirmishes with Azerbaijan. Some of these concerns may be prevalent in other low-to-middle-income countries (LMICs) with conflicts. Additional countries formerly part of the Soviet Union, a few of which are currently facing conflicts, have also faced similar challenges in transitioning from the Semashko model of healthcare, addressing social stigma around mental health, and developing modern psychiatric care $[33,39]$. It is critical to investigate and address mental health concerns in countries facing conflicts in the midst of the COVID-19 pandemic. 
Acknowledgements We thank Dr. Varduhi Petrosyan (American University of Armenia, Yerevan, Armenia) for reading and providing comments on the manuscript.

Funding This research did not receive any specific grant from funding agencies in the public, commercial, or not-for-profit sectors.

\section{Compliance with ethical standards}

Conflict of interest On behalf of all authors, the corresponding author states that there is no conflict of interest.

\section{References}

1. Statistical Committee of the Republic of Armenia (2020) Number of De Jure Population of the Republic of Armenia as of April 1, 2020. https://www.armstat.am/file/article/nasel_01.04.2020.pdf. Accessed 17 Jun 2020

2. Klever E (2013) The Nagorno-Karabakh conflict between Armenia and Azerbaijan: an overview of the current situation. European Movement. http://europeanmovement.eu/wp-content/uploa ds/2015/05/2013.09-Current-situation-Nagorno-Karabakh.pdf. Accessed 18 Jul 2020

3. Cavanaugh C (2017) Renewed conflict over Nagorno-Karabakh. The council on foreign relations-center for preventive action, contingency planning memorandum. https://cdn.cfr.org/sites/default/ files/report_pdf/ContingencyPlanningMemo30_Cavanaugh_0.pdf. Accessed 18 Jul 2020

4. Guterres A (2020) The fury of the virus illustrates the folly of war. https://www.un.org/en/un-coronavirus-communications-team/ fury-virus-illustrates-folly-war. Accessed 17 Jul 2020

5. Kucera J (2020) Fighting between Armenia and Azerbaijan widens. Eurasianet. https://eurasianet.org/fighting-between-armen ia-and-azerbaijan-widens. Accessed $2020 \mathrm{Jul} 15$

6. Hambling D (2020) Azerbaijan threatens chernobyl-style 'catastrophe' in caucasus drone war. Forbes. https://www.forbes.com/ sites/davidhambling/2020/07/17/threat-of-chernobyl-style-catas trophe-in-caucasus-drone-war/\#5031136c7946. Accessed $18 \mathrm{Jul}$ 2020

7. Solmi F, Dykxhoorn J, Kirkbride JB (2017) Urban-rural differences in major mental health conditions. In: Okkels N, Kristiansen C, Munk-Jørgensen P (eds) Mental health and illness in the city. Mental Health and illness worldwide. Springer, Singapore, pp $1-106$

8. Statistical Committee of the Republic of Armenia (2020) 1. Social-Economic Indicators. Food Security and Poverty, JanuaryMarch 2020. https://www.armstat.am/file/article/f_sec_1_2020_1. pdf. Accessed 18 Jul 2020

9. Paul KI, Moser K (2009) Unemployment impairs mental health: meta-analyses. J Vocat Behav 74:264-282. https://doi. org/10.1016/j.jvb.2009.01.001

10. Menjívar C, Agadjanian V (2007) Men's migration and women's lives: views from rural Armenia and Guatemala. Soc Sci Q 88:1243-1262. https://doi.org/10.1111/j.1540-6237.2007.00501 . $\mathrm{X}$

11. De Jong JT, Komproe IH, Van Ommeren M (2003) Common mental disorders in postconflict settings. Lancet 361:2128-2130. https ://doi.org/10.1016/S0140-6736(03)13692-6

12. Jayasuriya D, Jayasuriya R, Tay AK, Silove D (2016) Associations of mental distress with residency in conflict zones, ethnic minority status, and potentially modifiable social factors following conflict in Sri Lanka: a nationwide cross-sectional study. Lancet Psychiat 3:145-153. https://doi.org/10.1016/S2215-0366(15)00437-X
13. Karam EG, Howard DB, Karam AN, Ashkar A, Shaaya M, Melhem N, El-Khoury N (1998) Major depression and external stressors: the Lebanon Wars. Eur Arch Psychiatry Clin Neurosci 248:225-230. https://doi.org/10.1007/s004060050042

14. National Center for Disease Control of the Republic of Armenia (2020) [Confirmed cases by day]. https://ncdc.am/coronavirus/ confirmed-cases-by-days/. Accessed 21 Jul 2020

15. Roser M, Ritchie H, Ortiz-Ospina E, Hasell J (2020) Coronavirus Pandemic (COVID-19). Our World in Data. https://ourworldin data.org/coronavirus. Accessed 3 Aug 2020

16. Brooks SK, Webster RK, Smith LE, Woodland L, Wessely S, Greenberg N, Rubin GJ (2020) The psychological impact of quarantine and how to reduce it: rapid review of the evidence. Lancet 395:14-20. https://doi.org/10.1016/S0140-6736(20)30460-8

17. Pfefferbaum B, North CS (2020) Mental health and the Covid-19 pandemic. N Engl J Med. https://doi.org/10.1056/NEJMp20080 17

18. Statistical Committee of the Republic of Armenia (2018) Social Snapshot and Poverty in Armenia. https://www.armstat.am/file/ article/poverty_2018__eng.pdf. Accessed 12 Nov 2020

19. Liang X, Zhu Y, Fang Y (2020) COVID-19 and post-traumatic stress disorder: a vicious circle involving immunosuppression. CNS Neurosci Ther 26:876-878. https://doi.org/10.1111/ cns. 13431

20. Statistical Committee of the Republic of Armenia (2013) [5. Social Demographic sector]. [The results of the census conducted in the Republic of Armenia on October 12-21]. https://www.armst at.am/file/article/sv_03_13a_520.pdf. Accessed 18 Jul 2020

21. Koenig HG (2009) Research on religion, spirituality, and mental health: a review. Can J Psychiatry 54:283-291. https://doi. org/10.1177/070674370905400502

22. Grotberg EH (1997) Resilience and culture/ethnicity examples from Sudan, Namibia, and Armenia. In: 55th Annual convention of the international council of psychologists, Padua, Italy. https:// eric.ed.gov/?id=ED417860. Accessed 18 Jul 2020

23. Babajanian BV (2005) Civic participation in post-Soviet Armenia. Cent Asian Surv 24:261-279. https://doi.org/10.1080/0263493050 0310345

24. World Health Organization (2001) The World Health Report 2001: mental health: new understanding, new hope. https://www.who. int/whr/2001/en/whr01_en.pdf?ua=1. Accessed 25 Jul 2020

25. van Baelen L, Theocharopoulos Y, Hargreaves S (2005) Mental health problems in Armenia: low demand, high needs. Br J Gen Pract 55:64-65. https://www.ncbi.nlm.nih.gov/pmc/articles/ PMC1266262/pdf/bjpg55-064.pdf. Accessed 25 Jul 2020

26. Hovsepyan A (2018) The two sides of the mirror: coping with mental illness in the border towns. EVN Report. https://www. evnreport.com/raw-unfiltered/the-two-sides-of-the-mirror. Accessed 17 Jun 2020

27. Roberts B, Abbott P, McKee M (2010) Levels and determinants of psychological distress in eight countries of the former Soviet Union. J Public Ment Health 9:17-26. https://doi.org/10.5042/ jpmh.2010.0459

28. Roberts B, Abbott P, McKee M (2012) Changes in the levels of psychological distress in eight countries of the former Soviet Union. J Public Ment Health 11:141-152. https://doi. org/10.1108/17465721211261932

29. Demirchyan A, Petrosyan V, Thompson ME (2012) Gender differences in predictors of self-rated health in Armenia: a population-based study of an economy in transition. Int J Equity Health 11:67. https://doi.org/10.1186/1475-9276-11-67

30. Srapyan Z, Armenian HK, Petrosyan V (2006) Health-related quality of life and depression among older people in Yerevan, Armenia: a comparative survey of retirement home and household residents aged 65 years old and over. Age Ageing 35:190-193. https://doi.org/10.1093/ageing/afj039 
31. Khachadourian V, Armenian H, Demirchyan A, Melkonian A, Hovanesian A (2016) A post-earthquake psychopathological investigation in Armenia: methodology, summary of findings, and follow-up. Disasters 40:518-533. https://doi.org/10.1111/ disa. 12166

32. Illgner A (2016) Every house has bullet marks: life in a frozen war zone. The Guardian. https://www.theguardian.com/world/2016/ aug/02/living-in-one-of-europes-frozen-conflicts-movses-nagor no-karabakh. Accessed 17 Jun 2020

33. Petrea I (2012) Mental health in former Soviet countries: from past legacies to modern practices. Public Health Rev 34:5. https ://doi.org/10.1007/BF03391673

34. World Health Organization (2009) WHO-AIMS report on mental health system in Armenia. Yerevan: World Health Organization and Armenia Ministry of Health. https://www.who.int/menta 1_health/armenia_who_aims_report.pdf?ua=1. Accessed $18 \mathrm{Jul}$ 2020
35. Richardson E (2013) Armenia: health system review. Health Syst Transit 15:1-99. https://www.euro.who.int/_data/assets/ pdf_file/0008/234935/HiT-Armenia.pdf. Accessed 10 July 2020

36. McCarthy J, Harutyunyan H, Smbatyan M, Cressley H (2013) Armenia: Influences and organization of mental health services. Int J Adv Couns 35:100-109. https://doi.org/10.1007/s1044 7-012-9170-8

37. von Schoen-Angerer $\mathrm{T}$ (2004) Understanding health care in the south Caucasus: examples from Armenia. BMJ 329:562-565. https://doi.org/10.1136/bmj.329.7465.562

38. Bergmann S (2019) From mental illness to homelessness. https:// www.evnreport.com/raw-unfiltered/from-mental-illness-to-homel essness. Accessed 18 Jul 2020

39. Antoun J, Phillips F, Johnson T (2011) Post-Soviet transition: improving health services delivery and management. Mt Sinai J Med 78:436-448. https://doi.org/10.1002/msj.20261 